\title{
The assessment of potential operation of wastewater treatment plant by dynamic simulations
}

\author{
Ivana Pijáková, Ján Derco \\ Department of Environmental Engineering, Faculty of Chemical and Food Technology, \\ Slovak University of Technology, Radlinského 9, 81237 Bratislava, Slovak Republic \\ ivana.pijakova@stuba.sk
}

\begin{abstract}
In this study, Activated Sludge Model No. 1 (ASM1) was used for modelling of wastewater treatment plant. The operational data of municipal wastewater treatment plant (WWTP) were collected and treated. Experimental data and biological treatment technology were structured according to the mathematical model requirements. They were implemented into computer scheme of the plant. Very good agreement between the experimental and calculated MLSS and effluent concentrations of the monitored pollution indicators was obtained after calibration of the model. The calibrated model was used to analyze the influence of oxygen concentration in the reactor and the influence of the prepared substitution of anaerobic sludge stabilization by aerobic technology on effluent quality. Changes of oxygen concentration significantly influenced the effluent values of ammonium nitrogen and nitrate nitrogen. Considerable increase of MLSS resulted from dynamic simulations performed for biological treatment with aerobic sludge stabilization. In both cases the results of dynamic simulation indicate that the WWTP will comply with the effluent standard values.
\end{abstract}

Keywords: ASM1, dynamic simulation, biological processes, simulation program, wastewater

\section{Introduction}

Mathematical modelling has become a powerful tool for design and operation of activated sludge systems. Operational difficulties together with nutrient removal greatly increased the demand for process modelling. Considering the design, modelling has led to the identification of procedures to estimate the optimal or near optimal design configuration, reactor size, operational parameters and estimation of the expected response (Henze et al., 1987).

Activated sludge models (ASM's) rely on collected and measured data of the actual treatment process. In most studies these data are taken for granted and much emphasis is given on estimation of kinetics and stoichiometric coefficients of the model parameters. However, the model can be influenced more by the operational data in comparison to most of the model parameters (Meijer et al., 2001). The development of ASM's leads to a much better understanding of different treatment processes. An adequate wastewater characterization is one of the dominating factors for the quality of model predictions (Roeleveld et al., 2001). Municipal wastewater is composed of a complex mixture of organic substrates and biodegradation of different organic fractions. They have to be described separately to allow for an adequate model under dynamic conditions. Ekama and Marais (1979) divided the wastewater into two biodegradable fractions that are degraded in two different rates: A readily biodegradable fraction consists mainly of soluble organic matter and the slowly biodegradable fraction consists of large molecules, colloids and particles that have to be hydrolyzed before degradation. The distinction between these two fractions has been made on the basis of biological response, not on physical separation.

The results of dynamic simulations of the real WWTP using the Activated Sludge Model No. 1 (ASM1) are presented in the paper. The objective of dynamic simulations is to assess the treatment potential of the WWTP in Trenčianska Teplá after substitution of anaerobic sludge stabilization technology by aerobic stabilization.

\section{Theoretical}

For modelling of activated sludge process a wide variety of approaches has been developed. In 1986, the IAWPRC Activated Sludge Model No.1 (Henze et al., 1986) was published, summarizing earlier attempts at modelling carbonaceous oxidation, nitrification and denitrification. This model represents the state of the art in modelling the activated sludge process and is therefore implemented in almost all commercial software packages and is widely applied. ASM1 includes 8 biochemical processes, 13 process components and 19 biokinetic parameters (Henze et al., 1987). The model includes the following processes: aerobic and anoxic growth of heterotrophs, aerobic growth of autotrophs, decay of heterotrophs and autotrophs, amonification of soluble organic nitrogen, hydrolysis of entrapped 
organics and entrapped organic nitrogen. Single components, parameters and coefficients which are the base of the model are shown in Table 1 and Table 2.

The Monod type reaction kinetics is applied to describe the transformation of process components through biochemical process included in this concept. An example of the Monod type reaction rate $\rho_{1}$ for aerobic growth of the heterotrophic biomass process rate can be expressed as follows (Henze et al., 1987).

$$
\rho_{1}=\mu_{H}\left(\frac{S_{S}}{K_{S}+S_{S}}\right)\left(\frac{S_{o}}{K_{O, H}+S_{O}}\right) X_{B, H}
$$

where

$K_{O, H}$ - the oxygen half-saturation coefficient for heterotrophic biomass $\left[\mathrm{mol} \mathrm{l}^{-3}\right]$

$K_{S}$ - the substrate half-saturation coefficient for heterotrophic biomass [ $\left.\mathrm{mol} \mathrm{l}^{-3}\right]$

$S_{O}$ - the dissolved oxygen concentration [ $\left.\mathrm{mol} \mathrm{l}^{-3}\right]$

$S_{S}$ - the soluble biodegradable substrate concentration $\left[\mathrm{mol} \mathrm{l}^{-3}\right]$

$X_{B, H}-$ the active heterotrophic biomass concentration $\left[\mathrm{mol} \mathrm{l}^{-3}\right]$
$\mu_{H}-$ the maximum growth-rate of heterotrophic biomass $\left[\mathrm{d}^{-1}\right]$

\section{Materials and methods}

\section{WWTP of Trenčianska Teplá}

The object of this study is WWTP in Trenčianska Teplá, the Slovak Republic. It consists of mechanical and biological stage with anaerobic sludge stabilization. Mechanical stage consists of screenings and primary clarifier. The volume of aeration tank is $520 \mathrm{~m}^{3}$. It is operating as oxic reactor with the average value of dissolved oxygen concentration equal $2.5 \mathrm{mg} \mathrm{l}^{-1}$. Average value of wastewater inflow in 2011 to the biological stage of the WWTP was $6593 \mathrm{~m}^{3} \mathrm{~d}^{-1}$. The secondary clarifier provides the final quality of WWTP. There is one tank in operation with total volume $850 \mathrm{~m}^{3}$. The flow of return sludge is $2160 \mathrm{~m}^{3} \mathrm{~d}^{-1}$. The scheme of the WWTP can be seen in Figure 1. It was designed for total pollution load of 36,651 population equivalents (p.e.). However, in 2011 actual organic load corresponded to 5161 p.e. The average influent COD value was $93.9 \mathrm{mg} \mathrm{l}^{-1}$ and average $\mathrm{BOD}_{5}$ value was

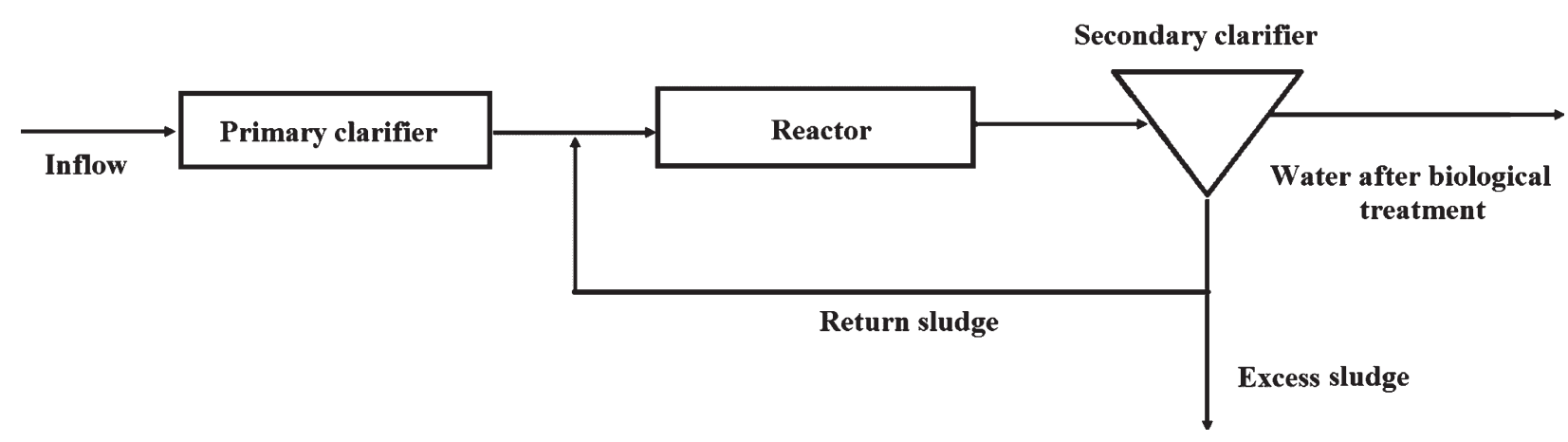

Fig. 1. Scheme of municipal WWTP.

Tab. 1. Influent concentration values for ASM1 - Trenčianska Teplá WWTP.

\begin{tabular}{lccc}
\hline Components & Symbol & Influent & Unit \\
\hline Dissolved oxygen & $S_{O}$ & 0.1 & $\mathrm{~g} \mathrm{COD} \mathrm{m}^{-3}$ \\
Inert soluble organic material & $S_{I}$ & 4.7 & $\mathrm{~g} \mathrm{COD} \mathrm{m}^{-3}$ \\
Readily biodegradable organic substrates & $S_{S}$ & 34.7 & $\mathrm{~g} \mathrm{COD} \mathrm{m}^{-3}$ \\
Ammonium + ammonia nitrogen & $S_{N H}$ & 15.3 & $\mathrm{~g} \mathrm{~N} \mathrm{~m}^{-3}$ \\
Nitrate + nitrite nitrogen & $S_{N O}$ & 0.7 & $\mathrm{~g} \mathrm{~N} \mathrm{~m}^{-3}$ \\
Soluble biodegradable organic nitrogen & $S_{N D}$ & 3.5 & $\mathrm{~g} \mathrm{~N} \mathrm{~m}^{-3}$ \\
Particulate biodegradable organic nitrogen & $X_{N D}$ & 7.3 & $\mathrm{mmol}^{-1}$ \\
Alkalinity of the wastewater & $S_{A L K}$ & 5.0 & $\mathrm{~g} \mathrm{COD} \mathrm{m}^{-3}$ \\
Inert particulate organic material & $X_{I}$ & 15.9 & $\mathrm{~g} \mathrm{COD} \mathrm{m}^{-3}$ \\
Slowly biodegradable substrates & $X_{S}$ & 24.4 & $\mathrm{~g} \mathrm{COD} \mathrm{m}^{-3}$ \\
Active heterotrophic biomass & $X_{B, H}$ & 14.1 & $\mathrm{~g} \mathrm{COD} \mathrm{m}^{-3}$ \\
Active autotrophic biomass & $X_{B, A}$ & 0 & $\mathrm{~g} \mathrm{COD} \mathrm{m}^{-3}$ \\
Particulate products arising from biomass decay & $X_{P}$ & 0 & \\
\hline
\end{tabular}

Pijáková I. et al., The assessment of potential operation of wastewater treatment plant... 
$38.1 \mathrm{mg} \mathrm{l}^{-1}$ (all data are given as yearly averages). Average influent concentration of ammonium nitrogen was $15.3 \mathrm{mg} \mathrm{l}^{-1}$ and average influent nitrate nitrogen concentration was $0.68 \mathrm{mg} \mathrm{l}^{-1}$. The average effluent COD value was $19.9 \mathrm{mg} \mathrm{l}^{-1}$ and average effluent $\mathrm{BOD}_{5}$ value was $3.8 \mathrm{mg} \mathrm{l}^{-1}$. Average effluent concentration of ammonium nitrogen was $3.13 \mathrm{mg} \mathrm{l}^{-1}$ and average concentration of nitrate nitrogen was $8.9 \mathrm{mg} \mathrm{l}^{-1}$.

\section{Results and discussion}

Simulation program ASIM 4.1 for dynamic simulations was used. In Table 1, the influent wastewater characteristics are given. Fractions of COD and nitrogen pollution were obtained experimentally using biodegradability tests (Holba, 2003). These values were used for simulations as the influent concentration data. The calibration was carried out with the aim to achieve minimum differences between the experimental and calculated mixed liquor suspended solids (MLSS) and pollution concentration values at effluent of the WWTP. In Table 2, values of the kinetic and stoichiometric parameters are summarised before and after calibration of the model.

The average temperature of $13{ }^{\circ} \mathrm{C}$ was used for simulations. The diurnal variation of influent was provided by the operator of the WWTP. The diurnal variation of composition was not available, so it was generated by using an algorithm which generates a matrix of hydrographs, describing the variable influent and composition to the WWTP at defined points in the time. This algorithm is implemented in SIMBA 6 simulation program (ifak, 2009). A very good agreement between the experimental and calculated mixed liquor suspended solids and effluent concentrations of the monitored pollution indicators $\left(\mathrm{COD}, \mathrm{NH}_{4}-\mathrm{N}\right.$, and $\left.\mathrm{NO}_{3}-\mathrm{N}\right)$ follows from Table 3. From the data in this table it follows that the calculated effluent concentration values are lower

Tab. 2. Kinetic parameters and coefficients.

\begin{tabular}{|c|c|c|c|}
\hline Parameter & Before calibration & After calibration & Unit \\
\hline $\begin{array}{l}\text { Maximum specific growth rate for heterotrophic } \\
\text { biomass }\left(\mu_{H}\right)\end{array}$ & 6.0 & 6.5 & {$\left[d^{-1}\right]$} \\
\hline $\begin{array}{l}\text { Maximum specific growth rate for autotrophic } \\
\text { biomass }\left(\mu_{A}\right)\end{array}$ & 0.8 & 1.0 & {$\left[d^{-1}\right]$} \\
\hline $\begin{array}{l}\text { Half-saturation coefficient for heterotrophic } \\
\text { biomass }\left(K_{S}\right)\end{array}$ & 20 & 70 & {$\left[\mathrm{~g} \mathrm{~m}^{-3}(\mathrm{COD})\right]$} \\
\hline $\begin{array}{l}\text { Ammonia half-saturation coefficient for } \\
\text { autotrophic biomass }\left(K_{N H}\right)\end{array}$ & 1.0 & 1.0 & {$\left[\mathrm{~g} \mathrm{~m}^{-3}\left(\mathrm{NH}_{4}-\mathrm{N}\right)\right]$} \\
\hline $\begin{array}{l}\text { Nitrate half-saturation coefficient for denitrifying } \\
\text { heterotrophic biomass }\left(K_{N O}\right)\end{array}$ & 0.5 & 0.4 & {$\left[\mathrm{~g} \mathrm{~m}^{-3}\left(\mathrm{NO}_{3}-\mathrm{N}\right)\right]$} \\
\hline $\begin{array}{l}\text { Oxygen half-saturation coefficient for } \\
\text { heterotrophic biomass }\left(K_{O H}\right)\end{array}$ & 0.2 & 0.2 & {$\left[\mathrm{~g} \mathrm{~m}^{-3}\left(\mathrm{O}_{2}\right)\right]$} \\
\hline $\begin{array}{l}\text { Oxygen half-saturation coefficient for autotrophic } \\
\text { biomass }\left(K_{O A}\right)\end{array}$ & 0.4 & 0.4 & {$\left[\mathrm{~g} \mathrm{~m}^{-3}\left(\mathrm{O}_{2}\right)\right]$} \\
\hline Decay coefficient for het. biomass $\left(b_{H}\right)$ & 0.62 & 2.0 & {$\left[d^{-1}\right]$} \\
\hline Decay coefficient for aut. biomass $\left(b_{A}\right)$ & 0 & 0.03 & {$\left[d^{-1}\right]$} \\
\hline Correction factor for $\mu_{H}$ under anoxic conditions $\left(\eta_{g}\right)$ & 0.8 & 0.8 & {$[-]$} \\
\hline Ammonification rate $\left(k_{a}\right)$ & 0.08 & 0.04 & {$\left[\mathrm{~m}^{3}(\mathrm{~g} \mathrm{COD} \mathrm{d})^{-1}\right]$} \\
\hline Maximum specific hydrolysis rate $\left(k_{h}\right)$ & 3.0 & 3.0 & {$\left[\mathrm{~g} \mathrm{COD}_{\mathrm{xS}}\left(\mathrm{g} \mathrm{COD}_{\mathrm{XH}} \mathrm{d}\right)^{-1}\right]$} \\
\hline $\begin{array}{l}\text { Half-saturation coefficient for hydrolysis of slowly } \\
\text { biodegradable substrate }\left(K_{x}\right)\end{array}$ & 0.03 & 0.03 & {$\left[\mathrm{~g} \mathrm{COD}_{\mathrm{xS}}\left(\mathrm{g} \mathrm{COD}_{\mathrm{xH}}\right)^{-1}\right]$} \\
\hline $\begin{array}{l}\text { Correction factor for hydrolysis under anoxic } \\
\text { conditions }\left(\eta_{h}\right)\end{array}$ & 0.4 & 0.4 & {$[-]$} \\
\hline Yield for heterotrophic biomass $\left(Y_{H}\right)$ & 0.67 & 0.67 & {$\left[\mathrm{~g} \mathrm{COD}_{\text {Хв }} \mathrm{g} \mathrm{COD}_{\mathrm{OX}}^{-1}\right]$} \\
\hline Yield for autotrophic biomass $\left(Y_{A}\right)$ & 0.24 & 0.24 & {$\left[\mathrm{~g} \mathrm{COD}_{\mathrm{XB}} \mathrm{g} \mathrm{N}_{\mathrm{Ox}}^{-1}\right]$} \\
\hline $\begin{array}{l}\text { Fraction of biomass leading to particulate } \\
\text { products }\left(f_{p}\right)\end{array}$ & 0.08 & 0.08 & {$[-]$} \\
\hline Mass of nitrogen per mass of COD in biomass $\left(i_{X B}\right)$ & 0.086 & 0.086 & {$\left[\mathrm{~g} \mathrm{~N}\left(\mathrm{~g} \mathrm{COD}_{\mathrm{XB}}\right)^{-1}\right]$} \\
\hline $\begin{array}{l}\text { Mass of nitrogen per mass of COD in products } \\
\text { from biomass }\left(i_{X P}\right)\end{array}$ & 0.06 & 0.06 & {$\left[\mathrm{~g} \mathrm{~N}\left(\mathrm{~g} \mathrm{COD}_{\mathrm{XP}}\right)^{-1}\right]$} \\
\hline
\end{tabular}


Tab. 3. Experimental and calculated 24-hour composite samples and effluent standard values.

\begin{tabular}{lccccc}
\hline Parameter & Unit & Measurement & Calculated & WWTP effluent standards & $\sigma[\%]$ \\
\hline MLSS & $\mathrm{g} \mathrm{l}^{-1}$ & 1.69 & 1.67 & - & 1.2 \\
$\mathrm{COD}$ & $\mathrm{mg} \mathrm{l}^{-1}$ & 19.9 & 19.8 & 120 & 0.5 \\
$\mathrm{NH}_{4}-\mathrm{N}$ & $\mathrm{mg} \mathrm{l}^{-1}$ & 3.13 & 3.7 & 20 & 18.2 \\
$\mathrm{NO}_{3}-\mathrm{N}$ & $\mathrm{mg} \mathrm{l}^{-1}$ & 8.9 & 9.7 & - & 9.0 \\
\hline
\end{tabular}

than related effluent standard values. The concentration total nitrogen was not measured because the load of the WWTP was less than 10000 p.e. that time.

Dynamic simulations with the calibrated ASM1 were focused on the investigation of influence of oxygen concentration in biological stage on effluent concentration values. Another aim was the prediction of the output values after substitution of anaerobic sludge stabilization technology by aerobic sludge stabilization.

\section{Influence of oxygen concentration in biological stage on effluent quality}

The oxygen concentration in reactor was measured online every hour. In 2011 average value of oxygen was $2.5 \mathrm{mg} \mathrm{l}^{-1}$, minimum value was $1.0 \mathrm{mg} \mathrm{l}^{-1}$ and maximum value was $6.3 \mathrm{mg} \mathrm{l}^{-1}$. Calibrated model (calibration performed in previous part) was used for the dynamic simulation. The results of simulations are presented in Table 4 . The results show the influence of oxygen concentration in the reactor on effluent concentration values. The results showed that the change in oxygen content in the reactor had no significant effect on the effluent values of COD and MLSS. Increase of oxygen concentration led to the decrease of ammonium nitrogen and consequently to significant increase of effluent nitrate nitrogen concentration. Obviously, an opposite effect on the values $\mathrm{NH}_{4}-\mathrm{N}$ and $\mathrm{NO}_{3}-\mathrm{N}$ was observed by decreasing the concentration of oxygen.

Tab. 4. Influence of oxygen content in the reactor on MLSS and effluent concentration values.

\begin{tabular}{lccc}
\hline \multirow{2}{*}{$\begin{array}{c}\text { Parameter } \\
{\left[\mathbf{m g ~ l}^{\mathbf{1}}\right]}\end{array}$} & \multicolumn{3}{c}{ Concentration oxygen in reactor $\left[\mathbf{m g ~ l}^{\mathbf{1}}\right]$} \\
\cline { 2 - 4 } & $\mathbf{1 . 0}$ & $\mathbf{2 . 5}$ & $\mathbf{6 . 3}$ \\
\hline $\mathrm{MLSS}$ & 1693 & 1670 & 1687 \\
$\mathrm{COD}$ & 19.9 & 19.8 & 19.6 \\
$\mathrm{NH}_{4}-\mathrm{N}$ & 8.3 & 3.7 & 2.2 \\
$\mathrm{NO}_{3}-\mathrm{N}$ & 6.6 & 9.7 & 13.1 \\
\hline
\end{tabular}

\section{Change of the type of sludge stabilization}

The change of sludge stabilization technology is coupled with the change of solid retention time (SRT). In 2011 the average value of SRT was 3 days. On the other hand, aerobic sludge stabilization requires SRT at least 25 days. Thus, dynamic simulations were performed with SRT 25 days. From the results of simulations it can be concluded that the increase of SRT leads to lower values of COD and ammonium nitrogen in the outflow. As a consequence, the average concentration of nitrate nitrogen in effluent was higher than in case of anaerobic sludge stabilization. The change of SRT had the most significant influence on the value of MLSS. The value of MLSS increased six times in comparison with operation with anaerobic sludge stabilization. Table 5 summarizes the results of dynamic simulations for prediction of the effluent values after substitution of anaerobic sludge stabilization by aerobic sludge stabilization.

Tab. 5. Results of dynamic simulations after change of sludge stabilization technology.

\begin{tabular}{|c|c|c|}
\hline \multirow{2}{*}{$\begin{array}{c}\text { Parameter } \\
{\left[\mathrm{mg} \mathrm{l}^{-1}\right]}\end{array}$} & \multicolumn{2}{|c|}{ SRT $\left[d^{-1}\right]$} \\
\hline & 3 & 25 \\
\hline MLSS & 1670 & 10039 \\
\hline COD & 19.8 & 16.5 \\
\hline $\mathrm{NH}_{4}-\mathrm{N}$ & 3.7 & 0.1 \\
\hline $\mathrm{NO}_{3}-\mathrm{N}$ & 9.7 & 16.0 \\
\hline
\end{tabular}

\section{Conclusion}

The aim this work was to assess the operational potential of the wastewater treatment plant after substitution of anaerobic to aerobic sludge stabilization technology. The dynamic simulations of the real WWTP were performed in order to obtain predictions of the WWTP to variation of influent wastewater flow and composition. The impact of operational parameter values on predicted effluent water quality was also investigated.

Mathematical modelling of WWTP Trenčianska Teplá was carried out using simulator ASIM 4.0. Simulations were performed with real experimental data. Fractions of COD and nitrogen pollution were obtained experimentally using biodegradability tests. Very good agreement between the experimental and calculated MLSS and effluent concentrations of the monitored pollution indicators was obtained when a calibration of model was used. 
The influence of oxygen concentration in the reactor and influence of change of the technology of sludge stabilization on the effluent concentration values was studied applying calibrated ASM1 model. Moderate decrease of ammonium nitrogen and significant increase of effluent nitrate nitrogen was caused by increase of oxygen in biological stage as well as by the increase of solid retention time. Change of oxygen concentration had no significant effect on the values of COD and MLSS. On the other hand, increase of SRT leads to the six times increased value of MLSS. Consequently, value of COD slightly decreased after increasing of SRT. The results of dynamic simulations show that the WWTP will comply with the effluent standard values also after the change of anaerobic sludge stabilization by aerobic technology. It can be concluded that ASM1 represents powerful and perspective tool for assessment the state of WWTP.

\section{Acknowledgments}

The authors wish to thank the support from VEGA Grant $1 / 0734 / 12$.

\section{References}

Ekama GA, Marais GvR (1979): Dynamic behavior of the activated sludge process. J Water Pollut Control Fed, 51,534 .
Henze M, Grady CPL, Gujer W, Marais GvR, Matsuo T (1986): Activated sludge model No. 1, IAWPRC Task Group on Mathematical Modelling for Design and Operation of Biological Wastewater Treatment. IAWPRC London, Report July 1986.

Henze M, Grady CPL, Gujer W, Marais GvR, Matsuo T (1987): Activated sludge model No. 1, IAWQ Scientific and Technical report. No. 1, IAWPRC, London. ISSN: 1010-707X.

Holba M (2003): Využití výsledků laboratorních kinetických měření a matematického modelování pro zlepšení funkce ČOV s technologiemi odstraňování nutrietů (PhD Thesis). VŠCHT, Praha, FTVP.

ifak (2009). SIMBA 6 Retrieved 27 November 2009 from: http://www.ifak-system.com/products/ simulation-software/wastewatersimulation/simba-6. html.

Mejier SCF, van Loosdrecht MCM, Heijen JJ (2001). Metabolic modelling of full-scale biological nitrogen and phosphorus removing, WWTP's Water Res. 34 (14), 2711-2723.

Roeleveld PJ, van Loosdrecht MCM (2001): Experiences with guidelines for wastewater characterization in The Netherlands. In Activated Sludge Modelling Fifth Kollekolle Seminar 2001: Modelling of Activated Sludge Processes in Theory and Practise, Denmark, 10-12 September 2001. 121-129. 